\title{
Reaction of Malononitrile and Ethyl Cyanoacetate: a Novel Synthesis of Polyfunctional Pyridine Derivatives
}

\author{
R. M. Mohareb and S. M. Fahmy* \\ Chemistry Department, Faculty of Science, Cairo University, Giza, Egypt \\ Z. Naturforsch. 40b, 1537-1540 (1985); received April 30, 1985 \\ Malononitrile, Ethyl Cyanoacetate, Pyridine Derivatives \\ Malononitrile reacts with ethyl cyanoacetate to give a polyfunctional substituted pyridine \\ derivative 5. The latter compound reacts with aniline, hydrazines and aromatic aldehydes to give \\ condensated products. The active methylene of $\mathbf{5}$ couples with benzenediazonium chloride to give \\ the phenylhydrazone derivative which cyclises readily to give a pyrido[2,3-d]pyridazine deriva- \\ tive. 5 reacts with trichloroacetonitrile, and carbon disulphide to give fused heterocyclic deriva- \\ tives.
}

Polyfunctional substituted pyridines are versatile reagents specially as precursors for synthesis of the fused heterocyclic pyridine derivatives $[1,2]$. In a recent article we have reported for the synthesis and the chemistry of 2-pyridothione derivatives using cyanothioacetamide as starting material [3]. In continuation of this program we report here for the synthesis of a new polyfunctional pyridine derivative starting with malononitrile (1) and ethyl cyanoacetate (2). The latter two reagents were reported by isation of malononitrile in the basic medium [5] to give compound $\mathbf{3}$, the latter inturn reacts with ethyl cyanoacetate to give ethyl $\alpha$-(2,4-diamino-3,5-dicyano-6-pyridinyl)acetate (5). Such pyridine formation finds parallism with the reported literature [6]. This reaction sequence is strictly confirmed via direct fusion of equimolecular amounts of malononitrile dimer (3) with ethyl cyanoacetate in presence of piperidine where $\mathbf{5}$ was obtained again but in a better yield. However, it is worthy to mention here that
2

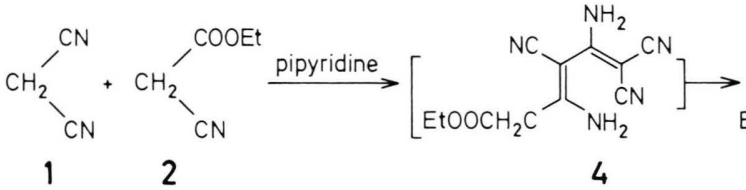

Junek et al. [4] to react together in sodium ethoxide solution to give ethyl 2-cyano-3-amino crotonoate. However, we found that fusion of the two reagents together in 2:1 molar ratio in presence of a catalytic amount of piperidine, a product of molecular formula $\mathrm{C}_{11} \mathrm{H}_{11} \mathrm{~N}_{5} \mathrm{O}_{2}$ was obtained. Structure 5 was proposed for the reaction product based on IR spectrum which revealed the presence of two amino stretching bands at $3450-3200 \mathrm{~cm}^{-1}$, two cyano stretching bands at $2225,2220 \mathrm{~cm}^{-1}$ and an ester carbonyl group at $1720 \mathrm{~cm}^{-1} .{ }^{1} \mathrm{H}$ NMR data revealed the presence of a singlet at $\delta 3.01 \mathrm{ppm}$ for $\mathrm{CH}_{2}$ group and the presence of four $\mathrm{D}_{2} \mathrm{O}$ exchangeable protons for two $\mathrm{NH}_{2}$ groups at $\delta 7.35$ and $7.58 \mathrm{ppm}$. A logical mechanism for this reaction is based on first dimer-

\footnotetext{
* Reprint requests to Dr. S. M. Fahmy.
}

Verlag der Zeitschrift für Naturforschung, D-7400 Tübingen $0340-5087 / 85 / 1100-1537 / \$ 01.00 / 0$ preparation of $\mathbf{5}$ via the former method is much more favourable for the easyness of the procedure, simplicity of the starting materials and saving of time. However, the chemistry of $\mathbf{5}$ presents further confirmation for the proposed structure.<smiles>CCOC(=O)/C(C#N)=C(\N)CC#N</smiles>

The reactivity of the ethyl carboxylate group of $\mathbf{5}$ towards amines and hydrazines finds parallism to the reported literature [7]. Thus, 5 condenses with aniline and hydrazines to give the anilide and hydrazide derivatives $\mathbf{6 a}-\mathbf{c}$, respectively. The structures of $\mathbf{6 a - c}$ were identified based on analytical and spectral data. 
Table I. List of compounds $5,6 \mathbf{a}-\mathbf{c} ; \mathbf{7 a}, \mathbf{b} ; \mathbf{8 , 9}, \mathbf{1 1}, \mathbf{1 3}, 14$ and 16.

\begin{tabular}{|c|c|c|c|c|c|c|c|}
\hline \multirow[t]{2}{*}{$\begin{array}{l}\text { Compound } \\
\text { (colour) }\end{array}$} & \multirow[t]{2}{*}{$\begin{array}{l}\text { Cryst. } \\
\text { solvent }\end{array}$} & \multirow[t]{2}{*}{$\begin{array}{l}\text { M.p. } \\
{\left[{ }^{\circ} \mathrm{C}\right]}\end{array}$} & \multirow[t]{2}{*}{$\begin{array}{l}\text { Yield } \\
{[\%]}\end{array}$} & \multirow[t]{2}{*}{$\begin{array}{l}\text { Mol. formula } \\
\text { [Mol. weight] }\end{array}$} & \multicolumn{2}{|c|}{$\begin{array}{l}\text { Analysis } \\
\text { Found (required) }\end{array}$} & \multirow[b]{2}{*}{$\mathrm{N}$} \\
\hline & & & & & $\mathrm{C}$ & $\mathrm{H}$ & \\
\hline 5 (yellow) & DMF & darkens at 295 & $\begin{array}{l}65(\text { method a }) \\
80(\text { method } b)\end{array}$ & $\begin{array}{l}\mathrm{C}_{11} \mathrm{H}_{11} \mathrm{~N}_{5} \mathrm{O}_{2} \\
(245)\end{array}$ & $\begin{array}{c}54.12 \\
(53.87)\end{array}$ & $\begin{array}{c}4.33 \\
(4.48)\end{array}$ & $\begin{array}{l}28.64 \\
(28.57)\end{array}$ \\
\hline 6a (brown) & DMF & $>300$ & 68 & $\begin{array}{l}\mathrm{C}_{15} \mathrm{H}_{12} \mathrm{~N}_{6} \mathrm{O} \\
(282.29)\end{array}$ & $\begin{array}{l}61.0 \\
(61.63)\end{array}$ & $\begin{array}{c}4.12 \\
(4.14)\end{array}$ & $\begin{array}{l}28.56 \\
(28.76)\end{array}$ \\
\hline $\mathbf{6 b}$ (paleyellow) & DMF & $>300$ & 75 & $\begin{array}{l}\mathrm{C}_{9} \mathrm{H}_{9} \mathrm{~N}_{7} \mathrm{O} \\
(231)\end{array}$ & $\begin{array}{l}46.50 \\
(46.75)\end{array}$ & $\begin{array}{l}4.00 \\
(3.89)\end{array}$ & $\begin{array}{c}42.72 \\
(42.42)\end{array}$ \\
\hline 6c (paleyellow) & water-DMF & $>300$ & 72 & $\begin{array}{l}\mathrm{C}_{15} \mathrm{H}_{13} \mathrm{~N}_{7} \mathrm{O} \\
(322)\end{array}$ & $\begin{array}{c}60.39 \\
(60.55)\end{array}$ & $\begin{array}{l}3.75 \\
(4.03)\end{array}$ & $\begin{array}{c}30.76 \\
(30.43)\end{array}$ \\
\hline 7a (brown) & dioxan & $285-287$ & 88 & $\begin{array}{l}\mathrm{C}_{18} \mathrm{H}_{15} \mathrm{~N}_{5} \mathrm{O}_{2} \\
(333)\end{array}$ & $\begin{array}{l}65.00 \\
(64.86)\end{array}$ & $\begin{array}{l}4.70 \\
(4.50)\end{array}$ & $\begin{array}{l}20.72 \\
(21.02)\end{array}$ \\
\hline $7 \mathbf{b}$ (orange) & dioxan & $>300$ & 90 & $\begin{array}{l}\mathrm{C}_{18} \mathrm{H}_{15} \mathrm{~N}_{5} \mathrm{O}_{3} \\
(349)\end{array}$ & $\begin{array}{c}62.10 \\
(61.89)\end{array}$ & $\begin{array}{c}4.52 \\
(4.29)\end{array}$ & $\begin{array}{l}20.30 \\
(20.05)\end{array}$ \\
\hline 8 (brickred) & ethanol & 150 & 78 & $\begin{array}{l}\mathrm{C}_{17} \mathrm{H}_{15} \mathrm{~N}_{7} \mathrm{O}_{2} \\
(349)\end{array}$ & $\begin{array}{c}58.42 \\
(58.45)\end{array}$ & $\begin{array}{c}4.49 \\
(4.29)\end{array}$ & $\begin{array}{c}28.21 \\
(28.08)\end{array}$ \\
\hline 9 (brown) & DMF & $260-263$ & 72 & $\begin{array}{l}\mathrm{C}_{17} \mathrm{H}_{14} \mathrm{~N}_{6} \mathrm{O}_{3} \\
(350)\end{array}$ & $\begin{array}{c}57.99 \\
(58.28)\end{array}$ & $\begin{array}{l}4.35 \\
(4.66)\end{array}$ & $\begin{array}{c}24.21 \\
(24.00)\end{array}$ \\
\hline 11 (brown) & dioxan & $>300$ & 77 & $\begin{array}{l}\mathrm{C}_{9} \mathrm{H}_{7} \mathrm{~N}_{5} \mathrm{O}_{2} \\
(217.19)\end{array}$ & $\begin{array}{c}49.57 \\
(49.77)\end{array}$ & $\begin{array}{l}2.99 \\
(3.25)\end{array}$ & $\begin{array}{l}32.58 \\
(32.25)\end{array}$ \\
\hline 13 (yellow) & dioxan & $290-292$ & 69 & $\begin{array}{l}\mathrm{C}_{12} \mathrm{H}_{12} \mathrm{~N}_{6} \mathrm{O}_{3} \\
(248.26)\end{array}$ & $\begin{array}{c}49.69 \\
(49.99)\end{array}$ & $\begin{array}{l}4.00 \\
(4.20)\end{array}$ & $\begin{array}{l}29.19 \\
(29.16)\end{array}$ \\
\hline 14 (yellow) & DMF & $260-263$ & 60 & $\begin{array}{l}\mathrm{C}_{10} \mathrm{H}_{8} \mathrm{~N}_{8} \mathrm{O} \\
(256.11)\end{array}$ & $\begin{array}{l}46.11 \\
(46.80)\end{array}$ & $\begin{array}{l}3.67 \\
(3.19)\end{array}$ & $\begin{array}{c}43.89 \\
(43.75)\end{array}$ \\
\hline 16 (orange) & DMF & $230-231$ & 68 & $\begin{array}{l}\mathrm{C}_{12} \mathrm{H}_{11} \mathrm{~N}_{5} \mathrm{O}_{2} \mathrm{~S}_{2} \\
(321.25)\end{array}$ & $\begin{array}{c}44.61 \\
(44.86)\end{array}$ & $\begin{array}{l}3.13 \\
(3.45)\end{array}$ & $\begin{array}{l}21.45 \\
(21.80)\end{array}$ \\
\hline
\end{tabular}

The active methylene group of the side chain in $\mathbf{5}$ found to yield arylidine derivatives $\mathbf{7 a}, \mathbf{b}$ on condensation with benzaldehyde and salicylaldehyde respectively ( $c f$. Table II).

5 couples with benzenediazonium chloride to form the phenylhydrazone derivative $\mathbf{8}$. The latter readily cyclises in alcoholic sodium hydroxide solution to give the pyrido[2,3-d]pyridazine derivative 9. Structures of compounds $\mathbf{7 a}, \mathbf{b} ; \mathbf{8}$ and $\mathbf{9}$ were established based on analytical and spectral data ( $c f$. Table II).

Refluxing $\mathbf{5}$ in acetic/hydrochloric acid mixture gives a product identified as pyrido[4,3-b]pyridine derivative $\mathbf{1 1}$ based on analytical and spectral data. It seems that $\mathbf{1 1}$ formed via cyclisation of the non isolable intermediate 10. Moreover, $\mathbf{1 1}$ was also obtained on treating compound $\mathbf{6} \mathbf{a}$ under the same conditions mentioned for cyclisation of $\mathbf{5}$.

5 reacts also with trichloroacetonitrile to give a pyrido[4,3-b]pyridine derivative $\mathbf{1 3}$, which is logically formed through cyclisation of the non isolable intermediate $\mathbf{1 2}$ followed by hydrolysis of the trichloromethyl group as reported [8]. Moreover, compound $\mathbf{1 3}$ found to condense with hydrazine hydrate to give a pyrazolo $\left(3^{\prime}, 4^{\prime}: 7,8\right)$ pyrido[3,2-c]pyridine derivative 14. Structures of compounds 13,14 were identified based on analytical and spectral data ( $c f$. Tables I and II).

5 found to react with carbon disulphide in aqueous ammonium hydroxide solution at room temperature

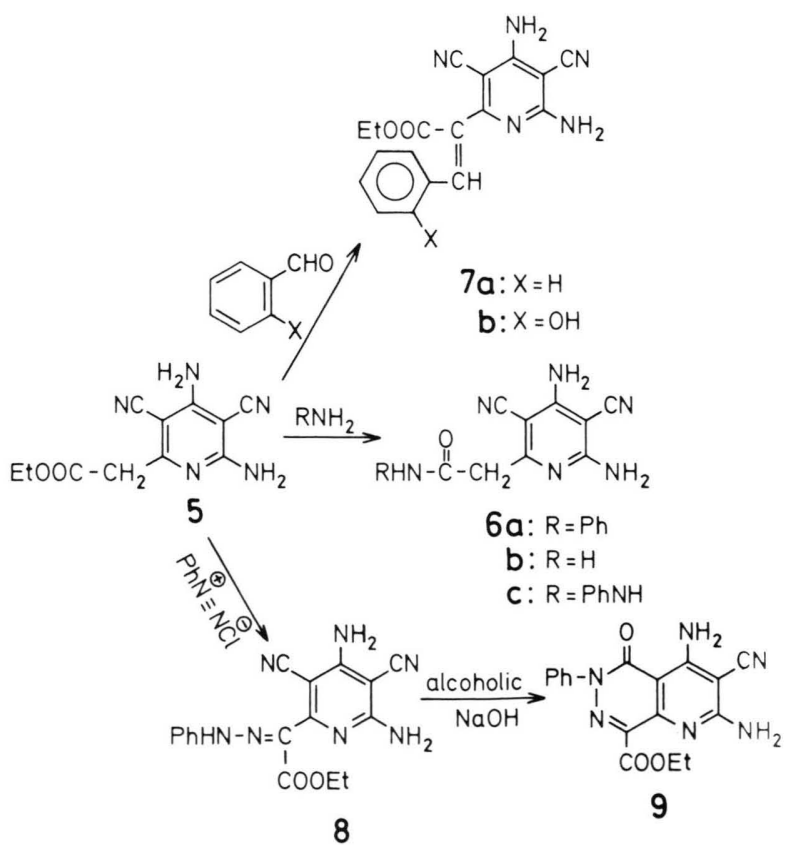


Table II. IR and ${ }^{1} \mathrm{H}$ NMR of compounds listed in Table I.

\begin{tabular}{|c|c|c|}
\hline Compound & IR $\left[\mathrm{cm}^{-1}\right]$ (selected bands) & ${ }^{1} \mathrm{H}$ NMR $[\mathrm{ppm}]$ \\
\hline 5 & $\begin{array}{l}3350,3200\left(2 \mathrm{NH}_{2}\right) ; 2950\left(\mathrm{CH}_{2}, \mathrm{CH}_{3}\right) ; 2225,2220 \\
(2 \mathrm{CN}) ; 1710(\text { ester } \mathrm{CO}) ; 1650\left(\delta \mathrm{NH}_{2}\right)\end{array}$ & $\begin{array}{l}1.68\left(\mathrm{t}, 3 \mathrm{H}, \mathrm{CH}_{3}\right) ; 3.85\left(\mathrm{~s}, 2 \mathrm{H}, \mathrm{CH}_{2}\right) ; 4.58(\mathrm{q}, 2 \mathrm{H}, \\
\left.\mathrm{CH}_{2}\right) ; 5.70\left(\mathrm{~s}, 2 \mathrm{H}, \mathrm{NH}_{2}\right) ; 7.23\left(\mathrm{~s}, 2 \mathrm{H}, \mathrm{NH}_{2}\right)\end{array}$ \\
\hline $6 \mathbf{a}$ & $\begin{array}{l}3450-3300\left(\mathrm{NH}_{2} \mathrm{NH}\right) ; 3050(\mathrm{CH} \text { aromatic }) ; 2980 \\
\left(\mathrm{CH}_{2}\right) ; 2225,2220(2 \mathrm{CN}) ; 1650-1630\left(\mathrm{NH}_{2},(\mathrm{NH}\right. \\
\text { deformation) }\end{array}$ & $\begin{array}{l}4.10\left(\mathrm{~s}, 2 \mathrm{H}, \mathrm{CH}_{2}\right) ; 4.99\left(\mathrm{~s}, 2 \mathrm{H}, \mathrm{NH}_{2}\right) ; 6.59(\mathrm{~s}, 2 \mathrm{H}, \\
\left.2 \mathrm{NH}_{2}\right) ; 7.33\left(\mathrm{~s}, 5 \mathrm{H}, \mathrm{C}_{6} \mathrm{H}_{5}\right) ; 10.34(\mathrm{~s}, \mathrm{br}, 1 \mathrm{H}, \mathrm{NH})\end{array}$ \\
\hline $6 b$ & $\begin{array}{l}3400-3200\left(3 \mathrm{NH}_{2} \text { and } \mathrm{NH}\right) ; 2980\left(\mathrm{CH}_{2}\right) ; 2225,2220 \\
(2 \mathrm{CN}) ; 1690(\mathrm{CO})\end{array}$ & $\begin{array}{l}3.80\left(\mathrm{~s}, 2 \mathrm{H}, \mathrm{CH}_{2}\right) ; 5.70\left(\mathrm{~s}, 2 \mathrm{H}, \mathrm{NH}_{2}\right) ; 7.53(\mathrm{~m}, 4 \mathrm{H}, \\
\left.2 \mathrm{NH}_{2}\right) ; 8.71(\mathrm{~s}, \mathrm{br}, 1 \mathrm{H}, \mathrm{NH})\end{array}$ \\
\hline $6 c$ & $\begin{array}{l}3350-3220\left(2 \mathrm{NH}_{2} \text { and } \mathrm{NH}\right) ; 2225-2220(2 \mathrm{CN}) \\
1685(\mathrm{CO}) ; 1640\left(\delta \mathrm{NH}_{2}\right)\end{array}$ & $\begin{array}{l}3.92\left(\mathrm{~s}, 2 \mathrm{H}, \mathrm{CH}_{2}\right) ; 5.68\left(\mathrm{~s}, 2 \mathrm{H}, \mathrm{NH}_{2}\right) ; 7.50(\mathrm{~s}, 2 \mathrm{H} \text {, } \\
\left.\mathrm{NH}_{2}\right) ; 8.89-9.0(2 \mathrm{~s}, \mathrm{br}, 2 \mathrm{NH})\end{array}$ \\
\hline $7 \mathbf{a}$ & $\begin{array}{l}3350,3200\left(2 \mathrm{NH}_{2}\right) ; 3010(\text { ylidene } \mathrm{CH}) ; 2225,2210 \\
(2 \mathrm{CN}) ; 1720(\text { ester CO }) ; 1640,1610\left(\delta \mathrm{NH}_{2} \text { and }\right. \\
\mathrm{C}=\mathrm{C})\end{array}$ & $\begin{array}{l}1.70\left(\mathrm{t}, 3 \mathrm{H}, \mathrm{CH}_{3}\right) ; 4.59\left(\mathrm{q}, 2 \mathrm{H}, \mathrm{CH}_{2}\right) ; 5.75(\mathrm{~s}, 2 \mathrm{H}, \\
\left.\mathrm{NH}_{2}\right) ; 7.23\left(\mathrm{~s}, 2 \mathrm{H}, \mathrm{NH}_{2}\right) ; 7.35-7.38(\mathrm{~m}, 6 \mathrm{H}, \\
\left.\text { ylidene } \mathrm{CH} \text { and } \mathrm{C}_{6} \mathrm{H}_{5}\right)\end{array}$ \\
\hline $7 \mathbf{b}$ & $\begin{array}{l}3450(\mathrm{OH}) ; 3300,3250\left(2 \mathrm{NH}_{2}\right) ; 2225,2220(2 \mathrm{CN}) \\
1650\left(\mathrm{dNH}_{2}\right)\end{array}$ & $\begin{array}{l}1.70\left(\mathrm{t}, 3 \mathrm{H}, \mathrm{CH}_{3}\right) ; 4.89\left(\mathrm{~s}, 2 \mathrm{H}, \mathrm{CH}_{2}\right) ; 5.76(\mathrm{~s}, 2 \mathrm{H}, \\
\left.\mathrm{NH}_{2}\right) ; 7.29\left(\mathrm{~s}, 2 \mathrm{H}, \mathrm{NH}_{2}\right) ; 7.35-7.40(\mathrm{~m}, 5 \mathrm{H}, \mathrm{CH}, \\
\left.\mathrm{C}_{6} \mathrm{H}_{4}\right) ; 10.10(\mathrm{~s}, 1 \mathrm{H}, \mathrm{OH})\end{array}$ \\
\hline 8 & $\begin{array}{l}3350,3310\left(2 \mathrm{NH}_{2}\right) ; 2220,2215(2 \mathrm{CN}) ; 1720 \text { (ester } \\
\mathrm{CO}) ; 1660\left(\delta \mathrm{NH}_{2}\right)\end{array}$ & $\begin{array}{l}1.69\left(\mathrm{t}, 3 \mathrm{H}, \mathrm{CH}_{3}\right) ; 5.45\left(\mathrm{~s}, 2 \mathrm{H}, \mathrm{NH}_{2}\right) ; 7.30(\mathrm{~s}, 2 \mathrm{H}, \\
\left.\mathrm{NH}_{2}\right) ; 7.35-7.39\left(\mathrm{~m}, 5 \mathrm{H}, \mathrm{C}_{6} \mathrm{H}_{5}\right) ; 10.23(\mathrm{~s}, \mathrm{br}, 1 \mathrm{H}, \\
\mathrm{NH})\end{array}$ \\
\hline 9 & $\begin{array}{l}3450,3300\left(2 \mathrm{NH}_{2}\right) ; 2220(\mathrm{CN}) ; 1720-1690(\text { ester } \\
\mathrm{CO} \text { and exocyclic } \mathrm{CO}) ; 1620\left(\delta \mathrm{NH}_{2}\right)\end{array}$ & Insoluble in common ${ }^{1} \mathrm{H}$ NMR solvents \\
\hline 11 & $\begin{array}{l}3450-3300\left(\mathrm{NH}_{2}, \mathrm{NH}\right) ; 2980\left(\mathrm{CH}_{2}\right) ; 2220(\mathrm{CN}) \\
1680,1700(2 \mathrm{CO}) ; 1630\left(\mathrm{NH}_{2}, \mathrm{NH} \text { deformation }\right)\end{array}$ & $\begin{array}{l}4.57\left(\mathrm{~s}, 2 \mathrm{H}, \mathrm{CH}_{2}\right) ; 5.75\left(\mathrm{~s}, 2 \mathrm{H}, \mathrm{NH}_{2}\right) ; 6.89(\mathrm{~s}, 2 \mathrm{H}, \\
\left.\mathrm{NH}_{2}\right) ; 10.00(\mathrm{~s}, \mathrm{br}, 1 \mathrm{H}, \mathrm{NH})\end{array}$ \\
\hline 13 & $\begin{array}{l}3500(\mathrm{OH}) ; 3450-3300\left(\mathrm{NH}_{2}, \mathrm{NH}\right) ; 2985\left(\mathrm{CH}_{2},\right. \\
\left.\mathrm{CH}_{3}\right) ; 2220(\mathrm{CN}) ; 1680(\text { ester } \mathrm{CO}) ; 1630\left(\mathrm{NH}_{2} \mathrm{de}-\right. \\
\text { formation) }\end{array}$ & Insoluble in common ${ }^{1} \mathrm{H}$ NMR solvents \\
\hline 14 & $\begin{array}{l}3450-3200\left(\mathrm{NH}_{2}, \mathrm{NH}\right) ; 2220(\mathrm{CN}) ; 1680(\text { ring } \mathrm{CO}) \\
1630\left(\mathrm{NH}_{2}, \mathrm{NH} \text { deformation }\right)\end{array}$ & Insoluble in common ${ }^{1} \mathrm{H}$ NMR solvents \\
\hline 16 & $\begin{array}{l}3450-3300\left(\mathrm{NH}_{2}, \mathrm{NH}\right) ; 2980\left(\mathrm{CH}_{2}, \mathrm{CH}_{3}\right) ; 2220 \\
(\mathrm{CN}) ; 1630\left(\mathrm{NH}_{2}, \mathrm{NH} \text { deformation }\right) ; 1200(\mathrm{C}=\mathrm{S})\end{array}$ & $\begin{array}{l}1.65\left(\mathrm{t}, 3 \mathrm{H}, \mathrm{CH}_{3}\right) ; 4.25\left(\mathrm{q}, 2 \mathrm{H}, \mathrm{CH}_{2}\right) ; 5.25(\mathrm{~s}, 2 \mathrm{H}, \\
\left.\mathrm{NH}_{2}\right) ; 7.01\left(\mathrm{~s}, 2 \mathrm{H}, \mathrm{NH}_{2}\right) ; 10.23(\mathrm{~s}, \mathrm{br}, 1 \mathrm{H}, \mathrm{NH})\end{array}$ \\
\hline
\end{tabular}
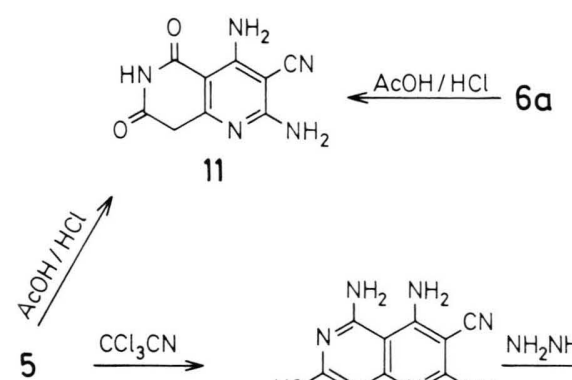<smiles>CCOC(=O)c1c(O)nc(N)c2c(N)c(CN)c(N)c(N)c12</smiles>

13<smiles>CCOC(=O)C(C(=S)S)c1nc(N)c(C#N)c(N)c1N</smiles>

15<smiles></smiles>

16 to give a thiopyrano[4,3-b]pyridine derivative $\mathbf{1 6}$. Formation of $\mathbf{1 6}$ is assumed to take place through cyclisation of the non isolable adduct $\mathbf{1 5}$.

\section{Experimental}

Melting points are uncorrected, IR spectra were recorded $(\mathrm{KBr})$ on a Pye-Unicam SP-1000. ${ }^{1} \mathrm{H}$ NMR spectra were obtained on an EM-90 MHz spectrometer in DMSO using TMS as internal standard and chemical shifts are expressed as ppm. Analytical data were performed by the microanalytical data Unit at Cairo University.

Preparation of ethyl $\alpha$-(2,4-diamino-3,5-dicyano-6-pyridinyl)acetate (5)

\section{$\operatorname{Method}(A)$}

A mixture of malononitril (1) $(1 \mathrm{~mol})$ and ethyl cyanoacetate $(0.05 \mathrm{~mol})$ containing $1 / 2 \mathrm{ml}$ of 
piperidine is heated in an oil bath at $140{ }^{\circ} \mathrm{C}$ for $40 \mathrm{~min}$ then left to cool. The product, so formed, is boiled in ethanol $(100 \mathrm{ml})$ then collected by filtration (cf. Tables I and II for data).

\section{Method (B)}

An equimolecular amounts $(0.1 \mathrm{~mol})$ of malononitrile dimer (3) and ethylcyanoacetate is heated in an oil bath at $140{ }^{\circ} \mathrm{C}$ for $30 \mathrm{~min}$. The solid product, so obtained, is boiled with $(70 \mathrm{ml})$ ethanol then collected by filtration.

Reaction of $\mathbf{5}$ with hydrazine and phenyl hydrazine to give the hydrazide derivatives $\mathbf{6} \mathbf{a}$ and $\mathbf{6} \mathbf{b}$, respectively

To a suspension of compound $5(0.01 \mathrm{~mol})$ in $30 \mathrm{ml}$ ethanol each of hydrazine hydrate or phenylhydrazine $(0.01 \mathrm{~mol})$ is added. The whole mixture is boiled under reflux for $2 \mathrm{~h}$ then poured into ice/water containing few drops of hydrochloric acid. The solid product, so formed is collected by filtration ( $c f$. Table I and II).

Reaction of $\mathbf{5}$ with benzaldehyde and salicylaldehyde to give arylidine derivatives $7 \mathbf{a}$ and $\mathbf{7 b}$, respectively

To a solution of compound $\mathbf{5}$ in DMF (30 ml) containing $1 / 2 \mathrm{ml}$ of piperidine, each of benzaldehyde or salicylaldehyde $(0.01 \mathrm{~mol})$ is added. The reaction mixture is heated under reflux for $1 \frac{1}{2} \mathrm{~h}$ then poured into ice/water mixture. The solid product, so formed, is collected by filtration ( $c f$. Tables I and II).

Coupling of $\mathbf{5}$ with benzenediazonium chloride to give the phenylhydrazone derivative $\mathbf{8}$

A solution of benzenediazonium chloride (prepared by adding sodium nitrite $(0.01 \mathrm{~mol})$ to the appropriate quantity of aniline in hydrochloric acid) is added to a stirred solution of $\mathbf{5}(0.01 \mathrm{~mol})$ in ethanol $(50 \mathrm{ml})$ and $5 \mathrm{ml}(5 \%)$ sodium hydroxide solution. The mixture is left at room temperature for $15 \mathrm{~min}$. The solid obtained is collected by filtration ( $c f$. Tables I and II).
Cyclisation of $\mathbf{8}$ to give the

pyrido[2,3-d]pyridazine derivative (9)

A solution of $8(0.01 \mathrm{~mol})$ in $50 \mathrm{ml}$ of ethanol containing 2 pellets of sodium hydroxide is heated under reflux for $3 \mathrm{~h}$ then evapourated in vacuo. The remaining product is triturated with water containing few drops of hydrochloric acid. The so formed solid product is collected by filtration ( $c f$. Tables I and II).

Cyclisation of $\mathbf{5}$ or $\mathbf{6 a}$ to give pyrido[4,3-b]pyridine derivative (11)

A solution of compound $\mathbf{5}(0.01 \mathrm{~mol})$ or $\mathbf{1 0}$ $(0.01 \mathrm{~mol})$ in acetic acid $(30 \mathrm{ml})$ and hydrochloric acid $(5 \mathrm{ml})$ mixture is heated under reflux for $6 \mathrm{~h}$ then left to cool. The reaction product is precipitated on adding sodium hydroxide solution $(0.1 \mathrm{~N})$ till $\mathrm{pH} 7$ then collected by filtration ( $c f$. Tables I and II).

\section{Reaction of $\mathbf{5}$ with trichloroacetonitrile to give $\mathbf{1 3}$}

To a solution of compound $5(0.01 \mathrm{~mol})$ in DMF $(30 \mathrm{ml})$ trichloroacetonitrile $(0.01 \mathrm{~mol})$ is added together with $1 / 2 \mathrm{ml}$ of triethylamine. The reaction mixture is left at room temperature overnight then poured into ice/water containing few drops of hydrochloric acid. The solid product, so formed is collected by filtration ( $c f$. Tables I and II).

\section{Reaction of $\mathbf{1 3}$ with hydrazine hydrate to give $\mathbf{1 4}$}

To a solution of compound $\mathbf{1 3}$ in $(0.01 \mathrm{~mol})$ in DMF $(30 \mathrm{ml})$ hydrazine hydrate $(0.01 \mathrm{~mol})$ is added. The reaction mixture is heated under reflux for $1 \mathrm{~h}$ then left to cool. The reaction product is precipitated on pouring into dilute hydrochloric acid/ice mixture then collected by filtration ( $c f$. Tables I and II).

Reaction of compound $\mathbf{5}$ with carbondisulphide to give 16

To a suspension of compound $\mathbf{5}(0.01 \mathrm{~mol})$ in ammonium hydroxide $(20 \%, 100 \mathrm{ml})$, carbondisulphide $(0.01 \mathrm{~mol})$ is added. The reaction mixture is left at room temperature overnight with constant stirring. The solid product, so formed, is collected by filtration ( $c f$. Tables I and II).
[1] M. J. R. Encians, C. Seoane, and I. L. Soto, Liebigs Ann. Chem. 1984, 213

[2] C. O. Okafor and R. N. Castle, J. Heterocycl. Chem. 20, 199 (1983)

[3] S. M. Fahmy and R. M. Mohareb, Tetrahedron (accepted 1985).

[4] H. Junek, P. Wibmer, and B. Thierrichter, Synthesis 1977, 560.
[5] R. A. Carboni, D. D. Coffman, and E. G. Howard, J. Am. Chem. Soc. 80, 2838 (1958)

[6] T. Takeshima, M. Yokoyama, N. Funkade, and M. Akano, J. Org. Chem. 35, 2438 (1970).

[7] S. M. Fahmy, N. Abed, R. M. Mohareb, and M. H. Elnagdi, Synthesis 1982, 490.

[8] F. M. Abdelrazek, N. S. Ibraheim, Z. El-Shabat, and M. H. Elnagdi, Synthesis 1984, 970. 